expansion passes through the spaces surrounding the pipe through which the compressed gas is passing to the point of expansion, and so makes this gas, still under pressure, cooler than it was itself while under compression. The compressed gas consequently becomes at the point of expansion cooler than that which preceded it, and in its turn follows backwards the course of the still compressed gas, and so makes the latter cooler than before expansion, and therefore also cooler than ever after expansion. This intensification of cooling (always assuming sufficient protection against access of heat from the outside) is only limited by the liquefaction of the gas, the temperature of liquefaction being in the case of oxygen $-180^{\circ} \mathrm{C}$. The apparatus exhibited measures 28 inches deep by 7 inches in diameter, and when once cooled down, that is, in about half an hour, it yields liquid oxygen at the rate of about seven cubic centimetres in four minutes. No carbonic acid, nitrous oxide, or other artificial cooling agent is employed either inside or outside the apparatus. With the liquid oxygen obtained, a series of interesting experiments were shown, which, however, were not in themselves new, such as the freezing of ether and alcohol, and the pulverisation of india-rubber after cooling. The expanded gas, after leaving the apparatus by the wide tube shown in the diagram, was led back to the suction pipe from which the pump was drawing. The impulse of the pump thus caused rhythmical variation in the pressure of the expanded gas over the surface of the liquid which had collected, and this in its turn produced a rhythmical variation in the small amount of ebullition visible in the liquid. Dr. Hampson's experiments, performed in the presence of a considerable number of representative men, constitute the first complete demonstration in England of the efficiency of the process of self-intensification of cold produced by expansion alone without the aid of extraneous artificial refrigeration.

It is obvious that the model exhibited admits of modification, both as to size and in some details of arrangement; but this ingenious adaptation of a well-known principle cannot fail to receive important practical applications. In the meantime the results already attained have the highest scientific interest. Among the more immediate consequences, we may look for the liquefaction of hydrogen in such quantities as to admit of the more exact study of the physical properties of this element in the liquid, and perhaps even in the solid state ; while following upon this, the attainment of, or approximation to, the absolute zero of temperature cannot be far off.

\section{ANIANUS JEDLIK.}

$\mathrm{O}^{\mathrm{N}}$ $\mathrm{N}$ the I2th of last December, a month before having completed his ninety-sixth year, Anianus Jedlik, who had for half a century been an active labourer in the field of experimental physics, ended his lengthy career at the cloister of the Benedictine Order, in Györ.

It was a strange sort of an investigator's life that came to a close with Jedlik's death. We scarcely meet with his name in the international literature of natural sciences, and yet he worked a great deal and wrote a great deal ; but he totally lacked the ambition to obtain the appreciation of foreign fellow-labourers in his branch of learning, for the results attained by him. To him, his researches in the world of physical phenomena afforded in themselves sufficient enjoyment; and his laboratory work thoroughly satisfied his unpretending nature, which was free from all desire for fame.

Stephen Jedlik, who as Benedictine monk adopted for his monastic name that of Anianus, was born on January II, I800, at Szimö, in the county of Komárom (Hungary). He frequented the Latin schools at Nagy
Szombat and Pozsony. In I8I7 he entered the bonds of the Benedictine Order at Pannonhalma, in 1822 he became Doctor of Philosophy, and in 1825 was consecrated officiating priest.

The talented young priest was intended by his Order for a professor, and so he was employed in teaching natural philosophy successively at Pannonhalma, Györ, and Pozsony. In 1840 he was appointed Professor of Natural Philosophy at the University of Pest.

Jedlik's scientific researches extended to various branches of natural philosophy; nevertheless he turned his attention principally to those physical phenomena which chiefly absorbed the learned men of the time at which he started upon his career, namely, those connected with galvanism and electro-magnetism.

Within the sphere of these, Jedlik succeeded in making two important discoveries, as we can prove with total certainty. But these discoveries now bear the names of others, who happened to make them independently of Jedlik, and hastened to make the scientific world acquainted with them, while he merely laid them before his own pupils.

It was in the first years of his professorship-in 1827 I 828--that, upon reading about electro-magnetism in the German periodicals to which he had access, he modified Schweigger's multiplicator in the following manner. $\mathrm{He}$ put in the place of the magnetic needle an electro-magnet and thus, with the aid of a current-commutator, produced permanent rotation.

Jedlik relates, in his modest manner, that he never came upon any mention of such electro-magnetic rotatory apparatus in any of the periodicals or works with which he was acquainted, so that he could not but believe that he was their discoverer. But he kept it to himself, as he had repeatedly experienced that descriptions of apparatus constructed by him after his own original ideas, already existed elsewhere; and so he never thought of sending descriptions of the above to any of the foreign scientific periodicals of which he knew.

Jedlik's other discovery had reference to the fundamental principle of the dynamo-electric machine. In the collection of the physical department of the University of Budapest, there is a machine of very primitive construction, dating, as it appears, from somewhere about the year I 860 , and probably the work of some méchanician of Pest, to which are joined directions as to its use in Jedlik's own handwriting.

In the fourth point of these instructions we find clearly defined the fundamental principle of the dynamo-electric engine, which principle Werner Siemens brought before the Academy of Berlin in 1867 , and according to which the magneto-electric currents of augmenting force may be developed by means of mechanical force, with the aid of the slight amount of magnetism contained in ordinary soft iron.

Jedlik discoursed with great zest upon his investigations at the meetings of natural philosophers and physicians, in whose publications his dissertations are to be found. Several of his treatises appeared in the publications of the Hungarian Academy of Sciences, which elected him its regular member in 1858 .

The topics of some of his more important treatises are as follows: "The Deflection of Beams" (I845); "The Application of the Electro-Magnet in Electro-Dynamic Rotations" (1856); "A Modification of Grove and Bunsen's Battery" (I857); "The Magneto-Motor" (1857); "Concatenation of Leyden Jars" (1863), through which peculiar modification he attained a remarkable degree of effect ; "Modification of Fresnel and Pouillet's Interference Apparatus" (I865); "Tubular Electric Collectors" (1867); "Electro-magnetic Undulation Machine" (1868).

With Jedlik there expired one of the typical figures of NO. I 379 , VOL. 53] 
the old school of physical experimenters who lacked that most important helper to their investigations-the knowledge of mathematics, but made up for this deficiency through a sort of intuitive perception when, led by a certain imaginative or creative faculty, they were able, with a sure hand, to grasp the very essence of a physical phenomenon.

With the present tendency of physical researches, this class of learned men could scarcely hold their ground ; but, on the other hand, we must not disdain these mere experimenters, for they count among their number no less a man than the great Faraday.

Augustus Heller.

\section{NOTES}

THE adoption of the metric system by the United States seems to have received a notable impulse during the present week by the action of the Committee of Congress, which has reported in favour of its use by the United States Government in all its affairs except the completion of land surveys now in progress, on and after July I, I898, and its general use through. out the country on the first day of the twentieth century, January r, I9or. The report is the outcome of a movement very early in this Session of Congress.

In accordance with a resolution of the House of Assembly of Cape Colony, carried last year, a Commission, consisting of the Hon. J. X. Merriman, Dr. Thomas Muir, Dr. David Gill, F.R.S., Mr. Thomas Stewart, and Mr. Charles Currey, has been appointed for the purpose of organising, controlling, and directing the work of geological exploration and survey in the colony. We are informed that the Commission has now appointed the under-mentioned gentlemen to begin the work of surveying and mapping the country:-Geologist, Dr. G. S. Corstorphine; Assistant Geologists, A. W. Rogers and E. H. L. Schwarz. As early as possible the Commission will publish and distribute a bibliography of South African geology.

IT has been decided by the Huxley Memorial Committee to strike a medal for award by the Royal College of Science, London, and possibly for other purposes. The Committee desire to obtain the design for the medal, if possible, by competition. Further particulars will be furnished on application, which must be sent in before May I to the Honorary Secretary of the Huxley Memorial Committee, Prof. G. B. Howes, Royal College of Science, South Kensington, S.W.

WE regret to see the announcement of the death of $\mathrm{Mr}$. Charles Chambers, F.R.S., Director of the Colába Observatory. For the following particulars of his career, we are indebted to a long notice in the Times of India. Mr. Chambers was born at Leeds, Yorkshire, on May 30, I834, and was consequently at the time of his demise in his sixty-second year. After finishing his education in his native place, he secured an appointment in the Kew Observatory, which he left in October I863, to take up the post of assistant to the Director and Chief Superintendent and Electrician of the Indo-European Telegraph Department, Persian Gulf Section. In October 1865, he was temporarily appointed Superintendent of the Government Observatory, Bombay. After acting in that capacity for over two years he was confirmed in the appointment in January 1868 , and continued to hold that office till November 1886, when he was given the appointment of Director of the Colába Observatory, which office he was holding at the time of his death. He was elected a Fellow of the Royal Society in 1869 . He was also appointed a Fellow of the Bombay University in 1872 , and a member of the Syndicate of the same University from I879 to I890. His contributions to scientific literature were very NO. I 379 , VOL. 53] numerous, most of them being records and discussions of meteorological and magnetic observations in relation to solar changes.

Prof. N. A. Moos, of the Elphinstone College, Bombay, has been selected for the post of Director of the Government Observatory at Colaba, in succession to the late $\mathrm{Mr}$. Charles Chambers.

THE Annual Congress of the British Institute of Public Health will be held in Glasgow, from July 23 to July 28 .

Dr. Samuel Wilks, F.R.S., was elected President of the Royal College of hysicians of London, at a meeting held on Monday.

Prof. Wyndham R. Dunstan, F.R.S., has been appointed Director of the Scientific Department of the Imperial Institute, which has hitherto been under the direction of Sir Frederick Abel. The principal work of this Department is to investigate new or little-known products from India and the Colonies, and to advise in reference to their commercial utilisation. Already much valuable work has been accomplished in this direction. With the aid of an increased grant from the Royal Commissioners of the $185 \mathrm{I}$ Exhibition further additions to the staff of the Department will be made, and the Laboratory, which was fitted up in 1894 with the assistance of a grant from the Goldsmiths' Company, will now be considerably extended.

THE College of New Jersey at Princeton is preparing to send an expedition to Patagonia for the purpose of securing fossils and large game. At a recent meeting of the Board of Trustees of the College, it was decided to change the charter name to Princeton University.

A FEW days ago M. Eugéne Fariot, an engineer of some repute and a worker in aeronautics, one of the siege aeronauts who escaped from Paris in the Louis Blanc, died at the age of sixty-eight. e has bequeathed a sum of $£ 4000$ to the Société française de Navigation Aerienne, of which he was a member. One half of this sum is to pay the expenses of experiments, and the other half to be funded in the name of the Society; the interest to be expended yearly on its behalf. Consequently, it is expected that an end will be put to the long stagnation in scientific aeronautics in France, owing to the indifference of the public authorities for an art so popular in that country.

For more than twenty years, the Sunday Society has been working "to obtain the opening of museums, art galleries, libraries, and gardens on Sundays." As already noted in these columns, the House of Commons on March Io passed, without a division, a resolution in favour of this object. We are glad now to record that in the House of Commons on Monday, in answer to Mr. Massey-Mainwaring, Mr. Balfour said: "The Government are prepared to open South Kensington and Bethnal Green at a very early date-indeed, almost immediately. Those are museums under the control of the President of the Council. The National Gallery, the National Portrait Gallery, and the British Museum are in the hands of trustees, and correspondence is still going on between the Government and the trustees, though I have no reason to believe that any difficulty need be apprehended as to the final conclusion of a satisfactory arrangement." In fulfilment of this promise, it was announced yesterday that the South Kensington Museum, including the India Museum and Science Collections in the Galleries on the west of Exhibition Road, as well as the Bethna Green Branch Museum, will be open on Sunday next at 2 p.m. and will remain open till dusk.

An instructive case for the consideration of anti-vaccinationists is reported in Wednesday's Times. It appears that the guardians 